\title{
Seabird segregation at Gulf Stream frontal eddies
}

\author{
J. Christopher Haney
}

Department of Zoology, University of Georgia, Athens, Georgia 30602, USA

\begin{abstract}
Eddies along the western frontal boundary of the Gulf Stream result in the episodic formation of physically and biologically distinct water masses at the continental shelf break (ca $200 \mathrm{~m}$ isobath) off the southeastern United States. Standardized counts of seabirds were made simultaneously with ship-board and satellite-derived (VHRR) hydrographic measurements in 3 eddy-associated water masses during July 1983, and in 4 water masses during August 1984. Two statistical models were used to test for significant relations between seabird species composition and these water masses. Contingency analyses of abundance data from both cruises revealed that seabird species were not distributed independently of water mass type $(p<.005)$. Tested against the null hypothesis of homogeneous species abundances, $85 \%$ of common (densities $\geq 0.5$ birds $\mathrm{km}^{-2}$ ) seabird species exhibited significant affinities for a single water mass. The aerially foraging and feeding black-capped petrel Pterodroma hasitata and bridled tern Sterna anaethetus were most abundant in oligotrophic Gulf Stream and warm filament water, respectively. Species foraging on the ocean surface and feeding for more prolonged periods, shearwaters Puffinus gravis and Calonectris diomedea and storm-petrels Oceanites oceanicus and Oceanodroma castro, were most abundant in the upwelled cold core of the eddy. Interspecific variation in seabird affinities for meso-scale ( 50 to $150 \mathrm{~km}$ ) water masses can be attributed to trophic segregation originating from species-specific foraging behaviors, and oceanographic processes that directly or indirectly influence prey availability. These patterns indicate that apex marine consumers parallel other taxa and trophic groups in their responses to environmental heterogeneity induced by western boundary currents. Gulf Stream frontal eddies persist at 'event' time scales (2 to $14 \mathrm{~d})$, thereby further suggesting that some seabirds are functionally integrated with marine communities affiliated with relatively small, ephemeral, and kinetic physical features.
\end{abstract}

\section{INTRODUCTION}

Frontal variations in the Gulf Stream western boundary current dominate many of the physical and biological processes occurring on the eastern United States continental shelf and slope (e.g. Wiebe et al. 1976, Lai \& Richardson 1977, Blanton et al. 1981, Lee et al. 1981). Gulf Stream frontal eddies upwell nitrate-rich water into the euphotic zone between Cape Hatteras, North Carolina and Cape Canaveral, Florida. Studies of the biological influences of these eddies on outer shelf waters have been limited to chlorophyll a, phytoplankton, and zooplankton distributions, or to the significance of eddy-associated upwelling on seasonal outer shelf and 'new' primary production (Atkinson et al. 1978, Bishop et al. 1980, Paffenhöfer 1980, Paffenhöfer et al. 1980, Yoder et al. 1981, 1983, Deibel 1985). The influences of eddies on higher trophic-level, surfaceforaging consumers have not been investigated, although effects of subsurface Gulf Stream upwelling events on the distributions of benthic and demersal fishes have been described (Brandt \& Wadley 1981, Magnuson et al. 1981, Atkinson \& Targett 1983).

Seabirds that inhabit tropical and subtropical oceans are readily related to surface oceanographic features because deep-diving species are absent, a clear distinction between pelagic and inshore species can be made, and trophically-influenced use of physicallydifferentiated marine habitats can be inferred (Diamond 1978, Pocklington 1979). This paper addresses the question of whether seabird species composition is influenced by the environmental heterogeneity induced by Gulf Stream frontal eddies. In addition, the analysis identifies ecological and behavioral factors which affect avian distribution, and discusses the implications of seabird integration with marine communities that correspond to these small-scale physical features. 

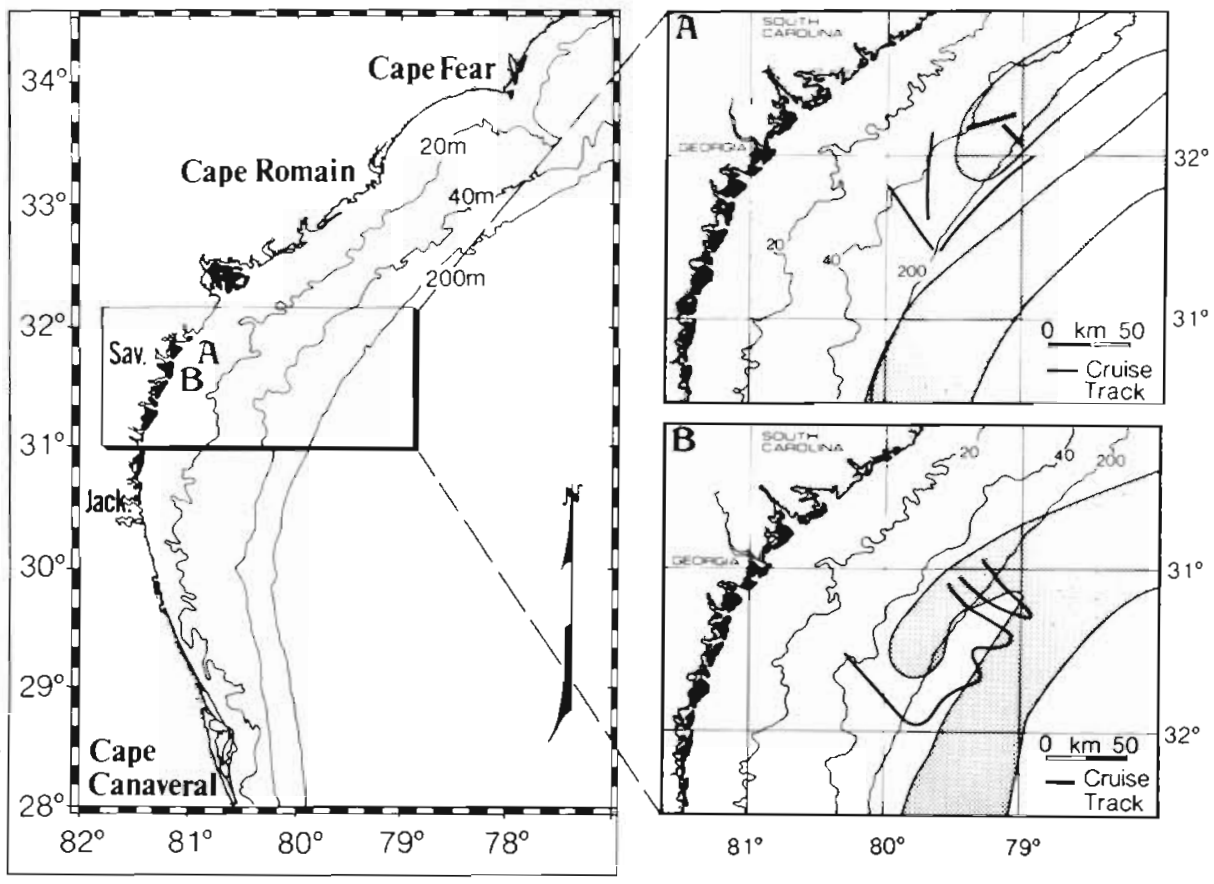

Fig. 1. The southeastern United States showing the study area in boxed inset. Daylight cruise tracks across Gulf Stream frontal eddies during July 1983 (A) and August 1984 (B) are shown in relation to water masses mapped by ship-board measurements and VHRR satellite composites. Shading indicates Gulf Stream and warm-filament water masses

\section{MATERIALS AND METHODS}

Seabird counts and hydrographic measurements were made from 14 to 15 July, 1983 (Cruise A) and 1 to 2 August, 1984 (Cruise B) on the Georgia and South Carolina outer continental shelf (Fig. 1). Water masses associated with Gulf Stream frontal eddies have definitive surface thermal profiles (Lee \& Atkinson 1983), and were identified by continuous sea surface temperature measurements recorded on a thermosalinograph, and by comparison of cruise tracks to Gulf Stream System Flow Charts (National Oceanic and Atmospheric Administration, Miami, Florida). These charts are derived from very high resolution satellite radiometry (VHRR) and map the thermal profiles of surface waters between $24^{\circ}$ and $35^{\circ} \mathrm{N}$ on $30^{\prime}$ latitude/ longitude blocks every $48 \mathrm{~h}$.

Spatially-continuous and temporally-consecutive ship-board counts of seabirds in water masses were made during daylight hours while vessels were underway. Seabird density estimates were obtained using a $90^{\circ}$ sector $300 \mathrm{~m}$ band transect (Tasker et al. 1984) and 15 min count period (Haney \& McGillivary 1985). Counts were conducted in 4 water masses on Cruise A $(\mathrm{n}=52)$ and 3 water masses on Cruise $\mathrm{B}(\mathrm{n}=80)$ (Table 1). Water masses were differentiated by using the maximum horizontal temperature gradient (front) as the between-mass boundary.

Two statistical models were used to examine whether seabird species' abundances were distributed independently of Gulf Stream eddy-associated water masses. Tests for the independence of the entire sea- bird assemblage (all species' abundances) and water mass type were first made with $3 \times 8$ (Cruise A) and $4 \times 8$ (Cruise B) contingency tables (Snedecor \& Cochran 1980). The affinities of individual seabird species for water masses were analyzed with Pearson's test for goodness of fit. Homogeneous expected cell probabilities were used under the null hypothesis of equal species' abundance in each water mass. Significant affinities were declared when the null hypothesis was rejected.

Prior to statistical analysis, all seabird abundances were first adjusted for differences in effort among water masses. All observed cell frequencies (total species numbers per water mass) were proportionately adjusted to the water mass with fewest counts (Table 1). By equivalently reducing sample size, this

Table 1 Summary of seabird count effort in Gulf Stream eddy-associated water masses

\begin{tabular}{|c|c|c|c|c|c|}
\hline Cruise & $\begin{array}{l}\text { Resi- } \\
\text { dent } \\
\text { shelf }\end{array}$ & $\begin{array}{l}\text { Warm } \\
\text { fila- } \\
\text { ment }\end{array}$ & $\begin{array}{l}\text { Cold } \\
\text { core }\end{array}$ & $\begin{array}{l}\text { Gulf } \\
\text { Stream }\end{array}$ & Total \\
\hline \multicolumn{6}{|l|}{ A: $14-15$ July 1983} \\
\hline Number of counts & 12 & 9 & 31 & - & 52 \\
\hline $\begin{array}{l}\text { Surface area } \\
\text { censused }\left(\mathrm{km}^{2}\right)\end{array}$ & 16.11 & 9.99 & 23.31 & - & 49.41 \\
\hline \multicolumn{6}{|l|}{ B: 1-2 August 1984} \\
\hline Number of counts & 14 & 25 & 34 & 7 & 80 \\
\hline $\begin{array}{l}\text { Surface area } \\
\text { censused }\left(\mathrm{km}^{2}\right)\end{array}$ & 15.54 & 27.75 & 37.74 & 7.77 & 88.8 \\
\hline
\end{tabular}


Table 2. Relative physical, chemical, and biological characteristics of Gulf Stream eddy-associated water masses

\begin{tabular}{|c|c|c|c|c|c|}
\hline & Resident shelf & Warm filament & Cold core & Gulf Stream & Source \\
\hline Surface temperature & Low & High & Low & High & $\begin{array}{l}\text { Lee \& Atkinson } 1983 \\
\text { Present study }\end{array}$ \\
\hline Surface salinity & Low & High & Medium & High & Lee \& Atkinson 1983 \\
\hline Clarity & Medium & High & Medium & High & Present study \\
\hline Horizontal circulation & Northward & Southward & $\begin{array}{l}\text { Cycionic } \\
\text { rotation }\end{array}$ & Northward & Pietrafesa \& Janowitz 1980 \\
\hline Vertical circulation & None & Downwelling & Upwelling & None & Pletrafesa \& Janowitz 1980 \\
\hline $\mathrm{NO}_{3}$ concentration & Low & Low & High & Low & Lee et al. 1981 \\
\hline Primary production & Low & Very low & High & Very low & Yoder et al. 1981, 1983 \\
\hline
\end{tabular}

robust procedure decreased the likelihood of rejecting the null hypothesis, and guarded against artifactual results stemming from differences in effort.

\section{RESULTS AND DISCUSSION}

Water masses encountered at Gulf Stream eddies strongly influenced the seabird assemblage characteristic of this geographic region. Frontal eddies consist of an entrained warm filament and a cyclonic, upwelled cold core situated between resident shelf and Gulf Stream water (Table 2, Fig. 2 \& 3). Prelimi- nary analyses of all seabird species frequencies from both cruises revealed that seabirds were not distributed independently of water mass type $\left(\chi^{2}=52.6\right.$, $\mathrm{p}<.005, \mathrm{df}=16$ for Cruise $\mathrm{A} ; \chi^{2}=61.9, \mathrm{p}<.005$ $\mathrm{df}=21$ for Cruise $\mathrm{B}$ ). In order to examine the departure from independence in more detail, the distributions of individual species' abundances were subjected to further chi-square tests.

Four of 8 seabird species on Cruise $A$ and 2 of 8 species on Cruise $B$ exhibited significant affinities for a single water mass (Tables 3 \& 4). A positive relation existed between species' maximum abundances and statistical significance (Fig. 4). None of the
Fig. 2. NOAA-6 satellite VHRR atmospherically-corrected thermal image of the Gu'f Stream on 23 April 1980 at 0019 UT. Light hues signify warm waters and dark hues cold. Arrows point to Gulf Stream frontal eddies. (Image processing and enhancement by Otis Brown and Bob Evans of the University of Miami)

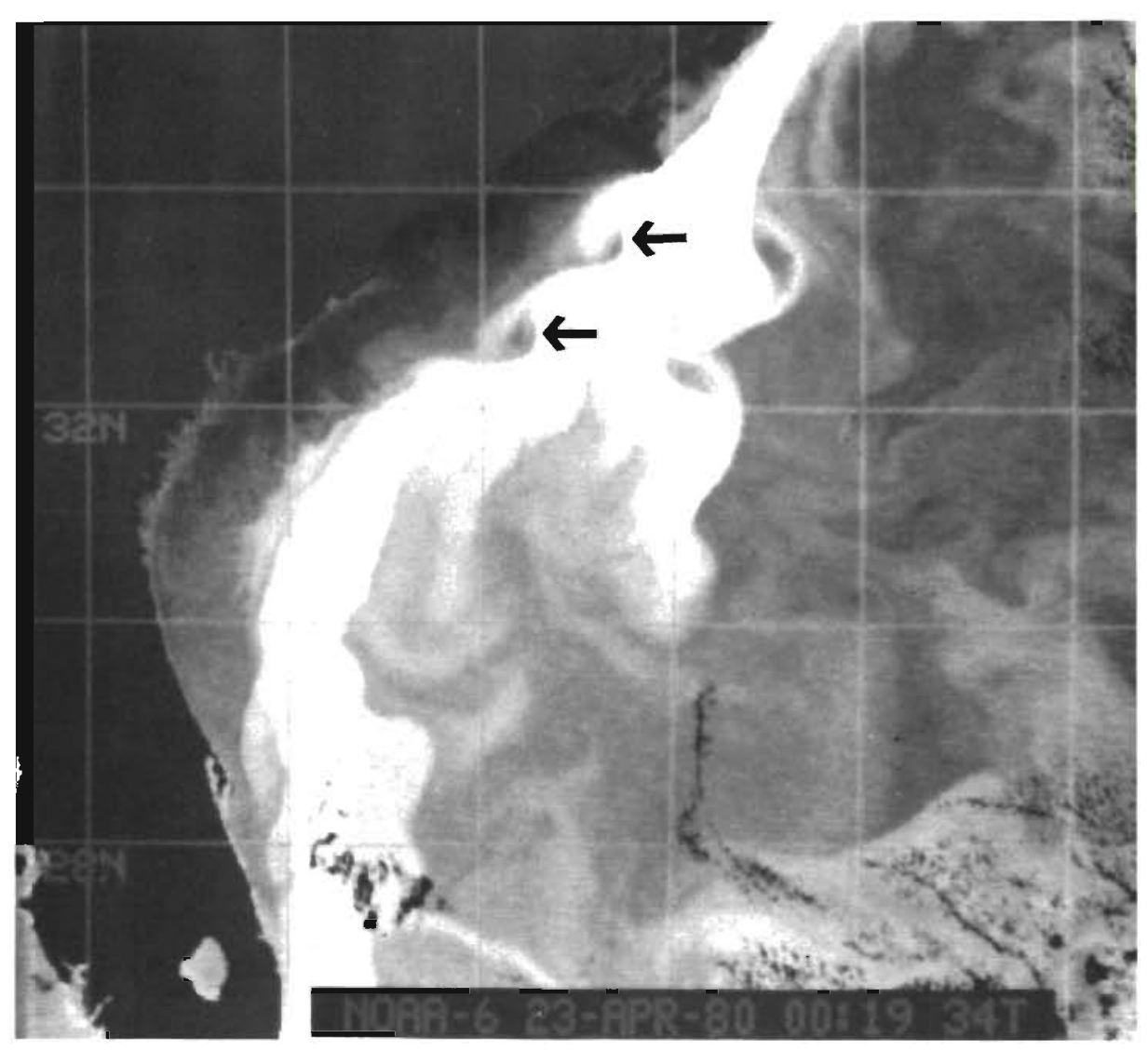


rare (densities $<0.5$ birds $\mathrm{km}^{-2}$ ) seabird species displayed significant water mass affinities. However, $85 \%$ of the common (densities $\geq 0.5$ birds $\mathrm{km}^{-2}$ ) species' abundances were unequally distributed among water mass types. Seabird species showed significant affinities for 3 of the 4 water masses, thus

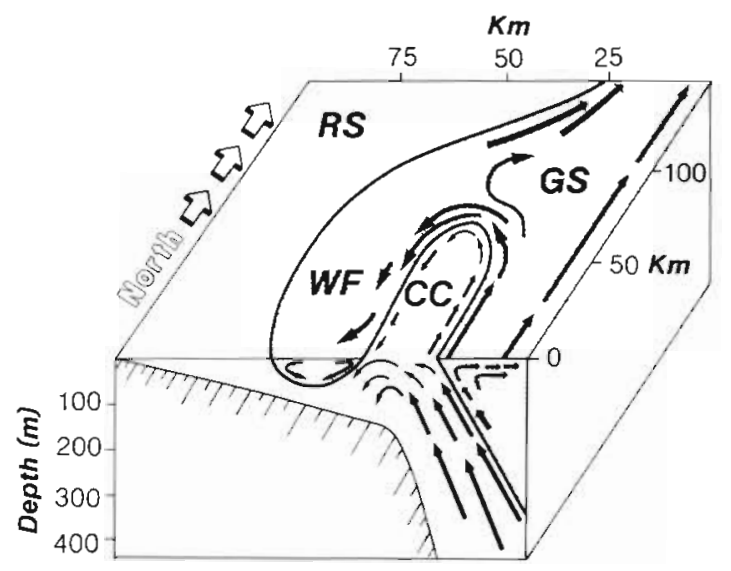

Fig. 3. Schematic representation of a Gulf Stream frontal eddy, associated water masses, and circulation at the continental shelf break of the southeastern United States. RS = resident shelf water; $W F=$ warm filament water, $\mathrm{CC}=$ cold core water; GS = Gulf Stream water making it unlikely that segregation was an artifact of association with regions of high productivity alone (cf. Tables $2,3 \& 4$ ).

Seabird species less interactive with the ocean surface during feeding and foraging (i.e. highly aerial) were most abundant in clear, oligotrophic water masses (Table 5). The piscivorous tem Sterna anaethetus feeds by hovering over the water and picking food from the surface or slightly beneath it (Clapp et al. 1983), and was confined to warm filament water. The gadfly petrel Pterodroma hasitata, foraging by dynamic soaring and feeding by surface or aerial dipping (Clapp et al. 1982), was most abundant in Gulf Stream water. Shearwaters and storm-petrels are more interactive with the ocean surface when foraging (Table 5), and were most abundant in the cold core of the eddy where primary productivity is highest (Yoder et al. 1981).

The relations of individual seabird species to Gulf Stream eddy-associated water masses may be explained by behavioral and structural adaptations for foraging, differential distribution of biomass (prey) among water mass types, and the physical attributes of water masses that favor certain foraging modes over others. The 2 species that occurred in water masses of

Table 3. Seabird affinities for water masses associated with a Gulf Stream eddy, Cruise A (14-15 July 1983)

\begin{tabular}{|c|c|c|c|c|c|c|c|c|}
\hline \multirow[t]{2}{*}{ Species } & \multicolumn{3}{|c|}{$\begin{array}{c}\text { Percent of species total } \\
\text { numbers in each water mass }\end{array}$} & \multicolumn{3}{|c|}{$\begin{array}{c}\text { Mean density (birds } \mathrm{km}^{-2} \text { ) } \\
\text { per water mass }\end{array}$} & \multicolumn{2}{|c|}{$\begin{array}{l}\text { Pearson's test for } \\
\text { goodness of fit }\end{array}$} \\
\hline & $\begin{array}{l}\text { Resident } \\
\text { shelf }\end{array}$ & $\begin{array}{l}\text { Warm } \\
\text { filament }\end{array}$ & $\begin{array}{l}\text { Cold } \\
\text { core }\end{array}$ & $\begin{array}{l}\text { Resident } \\
\text { Shelf }\end{array}$ & $\begin{array}{l}\text { Warm } \\
\text { filament }\end{array}$ & $\begin{array}{l}\text { Cold } \\
\text { core }\end{array}$ & $x^{2}$ & $\begin{array}{l}\text { Probability of } \\
\text { significance }\end{array}$ \\
\hline Pterodroma hasitata & 0 & 0 & 100 & 0 & 0 & 0.17 & 3.98 & NS \\
\hline Calonectris diomedea & 9 & 1 & 90 & 0.81 & 0.20 & 5.71 & 87.16 & $<.005$ \\
\hline Puffinus gravis & 0 & 0 & 100 & 0 & 0 & 0.69 & 14.02 & $<.005$ \\
\hline Puffinus Iherminierj & 13 & 25 & 62 & 0.06 & 0.20 & 0.21 & 0.5 & NS \\
\hline Oceanites oceanicus & 0 & 0 & 100 & 0 & 0 & 0.56 & 12.0 & $<.005$ \\
\hline Sula dactylatra & 0 & 100 & 0 & 0 & 0.10 & 0 & 2.02 & NS \\
\hline Sterna maxima & 0 & 100 & 0 & 0 & 0.10 & 0 & 2.02 & NS \\
\hline Sterna anaethetus & 0 & 100 & 0 & 0 & 1.60 & 0 & 32.02 & $<.005$ \\
\hline
\end{tabular}

Table 4. Seabird affinities for water masses associated with a Gulf Stream eddy, Cruise B (1-2 August 1984)

\begin{tabular}{|c|c|c|c|c|c|c|c|c|c|c|}
\hline \multirow[t]{2}{*}{ Species } & \multicolumn{4}{|c|}{$\begin{array}{c}\text { Percent of species total } \\
\text { numbers in each water mass }\end{array}$} & \multicolumn{4}{|c|}{$\begin{array}{c}\text { Mean density (birds } \mathrm{km}^{-2} \text { ) } \\
\text { per water mass }\end{array}$} & \multicolumn{2}{|c|}{$\begin{array}{l}\text { Pearson's test for } \\
\text { goodness of fit }\end{array}$} \\
\hline & $\begin{array}{l}\text { Resident } \\
\text { shelf }\end{array}$ & $\begin{array}{l}\text { Warm } \\
\text { filament }\end{array}$ & $\begin{array}{l}\text { Cold } \\
\text { core }\end{array}$ & $\begin{array}{l}\text { Gulf } \\
\text { Stream }\end{array}$ & $\begin{array}{l}\text { Resident } \\
\text { shelf }\end{array}$ & $\begin{array}{l}\text { Warm } \\
\text { filament }\end{array}$ & $\begin{array}{l}\text { Cold } \\
\text { core }\end{array}$ & $\begin{array}{l}\text { Gulf } \\
\text { Stream }\end{array}$ & $\chi^{2}$ & $\begin{array}{l}\text { Probability of } \\
\text { significance }\end{array}$ \\
\hline Pterodroma hasitata & 0 & 0 & 47 & 53 & 0 & 0 & 0.90 & 3.86 & 62.6 & $<.005$ \\
\hline Calonectris diomedea & 18 & 36 & 36 & 10 & 0.13 & 0.14 & 0.11 & 0.13 & 0.0 & NS \\
\hline Puffinus therminieri & 11 & 33 & 56 & 0 & 0.13 & 0.22 & 0.26 & 0 & 2.2 & NS \\
\hline Oceanites oceanicus & 4 & 4 & 85 & 7 & 0.06 & 0.04 & 0.64 & 0.25 & 5.9 & NS \\
\hline Oceanodroma leucorhoa & 0 & 0 & 100 & 0 & 0 & 0 & 0.05 & 0 & 3.0 & NS \\
\hline Oceanodroma castro & 0 & 0 & 100 & 0 & 0 & 0 & 0.45 & 0 & 12.0 & $<.01$ \\
\hline Stercorarius pomarinus & 0 & 0 & 100 & 0 & 0 & 0 & 0.03 & 0 & 3.0 & NS \\
\hline Sterna anaethetus & 0 & 100 & 0 & 0 & 0 & 0.18 & 0 & 0 & 6.0 & NS \\
\hline
\end{tabular}




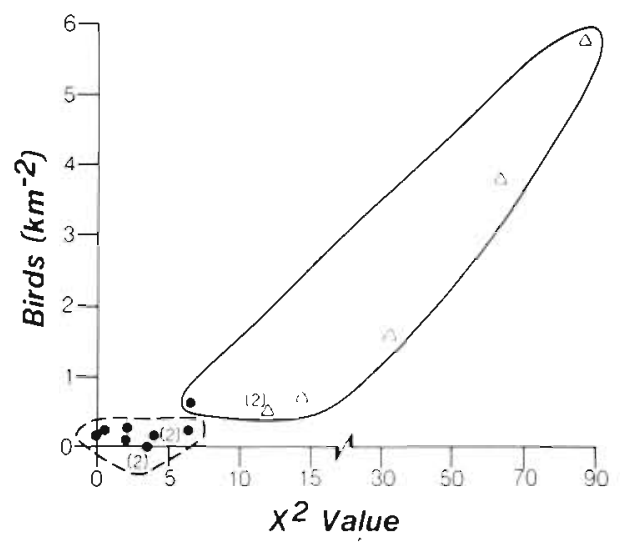

Fig. 4. Relations between maximum species abundance per water mass and statistical significance. $(\Delta) p<.05$; (•) nonsignificant affinity. Dashed line groups species occurrences with densities $<0.5$ birds $\mathrm{km}^{-2}$ and solid line groups species occurrences with densities $\geq 0.5$ birds $\mathrm{km}^{-2}$. Numbers in parentheses indicate more than 1 species at that graph point
Shearwaters and storm-petrels frequently come into contact with the ocean surface during feeding and were largely confined to the water mass with greatest biomass (Table 5). The high phytoplankton standing crops that result from Gulf Stream upwelling (Yoder et al. 1981, 1983) provide forage for herbivorous zooplankton (Paffenhöfer et al. 1984). The zooplanktivorous storm-petrel Oceanites oceanicus feeds by picking minute objects from the surface in rapid succession while using wings and feet to maintain a constant height above the uneven water surface. Oceanodroma castro feeds on zooplankton while sitting on the ocean (Lee 1984). Shearwaters were observed feeding on small, schooling baitfish (family: Carangidae) in the cold core of the eddy. The shearwater Calonectris diomedea feeds either on the ocean surface or by shallow $(<2 \mathrm{~m})$ diving. Puffinus gravis is also a surface-feeder, but may dive to greater depths (Brown et al. 1978). Since biomass is more concentrated in the

Table 5. Feeding methods of seabirds associated with Gulf Stream eddy water masses

\begin{tabular}{|c|c|c|c|}
\hline Species & Water mass affinity & Feeding method & Source \\
\hline Pterodroma hasitata & Gulf Stream & $\begin{array}{l}\text { Surface dipping } \\
\text { aerial dipping }\end{array}$ & $\begin{array}{l}\text { Ashmole } 1971 \\
\text { present study }\end{array}$ \\
\hline Calonectris diomedea & Cold core & Surface seizing & Ashmole 1971, Clapp et al. 1982 \\
\hline Puffinus gravis & Cold core & $\begin{array}{l}\text { Surface seizing: } \\
\text { pursuit diving }\end{array}$ & Ashmole 1971 \\
\hline Oceanites oceanicus & Cold core & Aerial dipping & Ashmole 1971 \\
\hline Oceanodroma castro & Cold core & Surface seizing & Lee 1984 \\
\hline Sterna anaethetus & Warm filament & Aerial seizing & Clapp et al. 1983 \\
\hline
\end{tabular}

low turbidity (Tables 2 \& 5) forage over large ambits (Haury et al. 1978), and search for scarce, widelydispersed prey in oligotrophic marine habitats. Neither Sterna anaethetus or Pterodroma hasitata is structurally adapted for diving (Ashmole 1971). The transparent water of the Gulf Stream and eddy warm filament may enable both of these highly aerial species to better detect their prey visually near the surface.

Differences between the water mass affinities of Sterna anaethetus and Pterodroma hasitata can be related directly to prey preference and distribution and indirectly to water mass circulation. Off the southeastern United States, $S$. anaethetus forages primarily for fish associated with large mats of pelagic Sargassum (Dooley 1972, Bortone et al. 1977, Duncan \& Havard 1980). All S. anaethetus were observed at large patches of Sargassum in the shallow, warm filament of the eddy where convergent circulation, or downwelling, aggregates the alga (cf. Tables 2 \& 3; Fig. 3; Pietrafesa \& Janowitz 1980, Butler et al. 1983). P. hasitata preferred the deeper, oceanic (Gulf Stream) water where its principal prey, cephalopods, are most abundant (cf. Clapp et al. 1982, Ainley et al. 1984). eddy cold core, seabird species can forage efficiently over smaller ambits, thus favoring more surfaceinteractive foraging behaviors (Table 5). Near-and onsurface foraging could also be selected for in these species if rates or probabilities of prey-detection are thereby increased in the less transparent water masses (cf. Ainley 1977).

Seabirds, as apex consumers in marine food webs, parallel lower trophic levels in their responses to western boundary current processes. The physical/biological gradients at eddies or rings influence community composition of phytoplankton (Ortner et al. 1979, Jeffrey \& Hallegraeff 1980), zooplankton (Ortner et al. 1978, Tranter et al. 1983), cephalopods (Brandt 1983), and midwater fishes (Brandt 1981, Olson \& Backus 1985). In the East Australian Current, changes in faunistic composition (Griffiths \& Brandt 1983, Tranter et al. 1983), abundance (McWilliam \& Phillips 1983), and size frequencies (Brandt 1983) were observed at eddies. Seabird segregation at eddies may in turn be the result of variability in the kinds, abundances, or size classes of their prey.

Seabird segregation of individual Gulf Stream fron- 
tal eddies is inevitably short-term. Gulf Stream eddies are small, episodic, and transient physical features on the southeastern United States continental shelf and slope. Compared to East Australian Current eddies and Gulf Stream rings (Wiebe et al. 1976), Gulf Stream eddies are smaller $(50 \times 150 \mathrm{~km}$ vs $300 \times 300 \mathrm{~km})$ and persist for shorter periods. Gulf Stream frontal eddies form and degrade in 2 to $14 \mathrm{~d}$ (Lee \& Brooks 1979, Lee et al. 1981) and move northward at speeds of 35 to $40 \mathrm{~km} \mathrm{~d}^{-1}$ (Legeckis 1979). The larger East Australian Current eddies and Gulf Stream rings are slower-moving $\left(13 \mathrm{~km} \mathrm{~d}^{-1}\right)$ and may persist for 12 to 24 mo (Nilsson \& Cresswell 1981). Although single Gulf Stream eddies are not long-lived features, one or more different eddies in varying stages of development are normally present along the shelf break (200 $\mathrm{m}$ isobath) between Cape Hatteras, North Carolina and Cape Canaveral, Florida. Distances between these eddies $(100$ to $400 \mathrm{~km})$ would allow highly mobile seabirds with large ambits to forage between features.

Segregation by seabirds at small and ephemeral physical features has not been previously investigated. Relations between seabird species or faunas and marine communities defined by surface temperature (Ashmole 1971), surface temperature and salinity (Pocklington 1979), and water clarity (Ainley 1977) were analyzed at larger, macro- (1000 to $3000 \mathrm{~km}$ ) scales. In a recent review, Hunt \& Schneider (in press) hypothesized that patterns for marine birds at larger scales are a response to physical features of the environment and that small-scale pattern is controlled primarily by biological processes of social interaction and foraging behavior. The results from this study do not support this dichotomous view. Rather, water mass segregation by seabirds can be perceived as a combination of both ultimate physical processes (circulation, water clarity) and more proximate biological influences (productivity, prey type and abundance, foraging behavior). The integrated manner in which seabirds are coupled to distinct, even temporary, water masses suggest a much tighter linkage between these consumers and marine communities than previously envisioned.

Acknowledgements. This research was supported by the NSF under grant OCE81-10707 to L. R. Pomeroy. Additional support was provided by the University of Georgia Department of Zoology and the Burleigh-Stoddard Fund. L. P. Atkinson, P. A. McGillivary, and J. Miller aided with information on Gulf Stream frontal eddies. The author thanks the captain and crew of the R/V 'Bluefin' for their assistance.

\section{LITERATURE CITED}

Ainley, D. G. (1977). Feeding methods in seabirds: a comparison of polar and tropical nesting communities in the eastern Pacific Ocean. In: Llano, G. A. (ed.) Adaptations within Antarctic ecosystems. Smithsonian Inst, Washington, D.C., p. 669-685

Ainley, D. G., O'Conner, E. F., Boekelheide, R. J. (1984). The marine ecology of birds in the Ross Sea, Antarctica. Ornithol. Monograph No. 32. American Ornithologist's Union, Washington, D.C.

Ashmole, N. P. (1971). Sea bird ecology and the marine environment. In: Farner, D. S., King, J. R. (ed.) Avian biology, Vol. 1. Academic Press, New York, p. 224-286

Atkinson, L. P., Paffenhöfer, G.-A., Dunston, W. M. (1978) The chemical and biological effect of a Gulf Stream intrusion off St. Augustine, Florida. Bull. mar. Sci. 28: 667-679

Atkinson, L. P., Targett, T. E. (1983). Upwelling along the 60-m isobath from Cape Canaveral to Cape Hatteras and its relationship to fish distribution. Deep Sea Res. 30 221-226

Bishop, S. S., Yoder, J. A., Paffenhöfer, G.-A. (1980). Phytoplankton and nutrient availability along a cross-shelf transect off Savannah, Georgia, U.S.A. Estuar. coast. mar Sci. 11: 359-368

Blanton, J. O., Atkinson, L. P., Pietrafesa, L. J., Lee, I N (1981). The intrusion of Gulf Stream water across the continental shelf due to topographically-induced upwelling. Deep Sea Res. 28: 393-405

Bortone, S. A., Hastings, P. M., Collard, S. B. (1977). The pelagic Sargassum ichthyofauna of the eastern Gulf of Mexico. Northeast Gulf Sci. 1: 60-67

Brandt, S. B. (1981). Effects of a warm-core eddy on fish distributions in the Tasman Sea off East Australia. Mar Ecol. Prog. Ser. 6: 19-33

Brandt, S. B. (1983). Pelagic squid associations with a warmcore eddy of the East Australian Current. Aust. J mar. Freshwat. Res. 34: 573-585

Brandt, S. B., Wadley, V. A. (1981). Thermal fronts as ecotones and zoogeographic barriers in marine and freshwater systems. Proc. Ecol. Soc. Aust. 11: 13-26

Brown, R. G. B., Bourne, W. R. P., Wahl, T. R. (1978). Diving by shearwaters. Condor 80: 123-125

Butler, J. N., Morris, B. F., Cadwallader, J., Stoner, A. W (1983). Studies of Sargassum and the Sargassum community. Bermuda Biol. Station. Spec. Publ. No. 22

Clapp, R. B., Banks, R., Morgan-Jacobs, D., Hoffman, W. A. (1982). Marine birds of the southeastern United States and Gulf of Mexico. Part I. Gaviiformes through Pelecaniformes. U.S. Fish Wildl. Serv., Washington, D.C.

Clapp, R. B., Morgan-Jacobs, D., Banks, R. C. (1983). Marine birds of the southeastern United States and Gulf of Mexico. Part IIl. Charadriiformes. U.S. Fish Wildl. Serv., Washington, D.C

Deibel, D. (1985). Blooms of the pelagic tunicate, Dolioletta gegenbauri: Are they associated with Gulf Stream frontal eddies? J. mar. Res. 43: 211-236

Diamond, A. W. (1978). Feeding strategies and population size in tropical seabirds. Am. Nat. 112: 215-223

Dooley, J. K. (1972). Fishes associated with the pelagic Sargassum complex, with a discussion of the Sargassum community. Contrib. mar. Sci, Univ, of Texas Mar. Sci. Inst. 16: $1-32$

Duncan, C. D., Havard, P. W. (1980). Pelagic birds of the northern Gulf of Mexico. Am. Birds 34: 122-132

Griffiths, F. B., Brandt, S. B. (1983). Mesopelagic crustacea in and around a warm-core eddy in the Tasman Sea off Eastern Australia. Aust. J. mar. Freshwat. Res. 34: 609-623

Haney, J. C., McGillivary, P. A. (1985). Aggregations of Cory's Shearwaters (Calonectris diomedea) at Gulf Stream fronts. Wilson Bull. 97 (2): 191-200

Haury, L. R., McGowan, J. A., Wiebe, P. H. (1978). Patterns 
and processes in the time-space scales of plankton distributions. In: Steele, J. M. (ed.) Spatial pattern in plankton communities. Plenum Press, New York, p. 277-327

Hunt, G. L., Schneider, D. C. (in press). Scale dependent processes in the physical and biological environment of marine birds. In: Croxall, J. D. (ed.) Seabird feeding. Cambridge Univ. Press, London

Jeffrey, S. W., Hallegraeff, G. M. (1980). Studies of phytoplankton species and photosynthetic pigments in a warmcore eddy of the East Australian Current. I. Summer populations. Mar. Ecol. Prog. Ser. 3: 285-294

Lai, D. Y., Richardson, P. L. (1977). Distribution and movement of Gulf Stream rings. J. phys. Oceanogr. 7: 670-683

Lee, D. S. (1984). Petrels and storm-petrels in North Carolina offshore waters: including species previously unrecorded for North America. Am. Birds 38: 151-163

Lee, T. N., Brooks, D. A. (1979). Initial observations of current, temperature, and coastal sea level response to atmospheric and Gulf Stream forcing on the Georgia shelf. Geophys. Res. Lett. 6: 321-324

Lee, T. N., Atkinson, L. P., Legeckis, R. (1981). Detailed observations of a Gulf Stream frontal eddy on the Georgia continental shelf, April 1977. Deep Sea Res. 28: 347-378

Lee, T. N., Atkinson, L. P. (1983). Low-frequency current and temperature variability from Gulf Stream frontal eddies and atmospheric forcing along the southeast U.S. outer continental shelf. J. Geophys. Res. 88: 4541-4567

Legeckis, R. (1979). Satellite observation of the influence of bottom topography on seaward deflection of the Gulf Stream off Charleston, South Carolina. J. phys. Oceanogr. 9: 483-497

Magnuson, J. J., Harrington, C. L., Stewart, D. J., Herbst, G. N. (1981). Responses of macrofauna to short-term dynamics of a Gulf Stream front on the continental shelf. In: Richards, F. A. (ed.) Coastal upwelling. Coastal and estuarine sciences, Vol. 1. Am. Geophys. Union, Washington, D.C., p. $441-448$

McWilliam, P. S., Phillips, B. F. (1983). Phyllosoma larvae and other crustacean macrozooplankton associated with eddy $\mathrm{J}$, a warm-core eddy off southeastern Australia. Aust. J. mar. Freshwat. Res. 34: 653-663

Nilsson, C. S., Cresswell, G. R. (1981). The formation and evolution of East Australian Current warm-core eddies. Prog. Oceanogr. 9: 134-183

Olson, D. B., Backus, R. H. (1985). The concentrating of organisms at fronts: a cold-water fish and a warm-core Gulf Stream ring. J. mar. Res. 43: 113-137

Ortner, P. B., Wiebe, P. H., Haury, L. R., Boyd, S. H. (1978).
Variability in zooplankton biomass distribution in the northern Sargasso Sea: the contribution of Gulf Stream cold-core rings. Fish. Bull. U.S. 76: 323-334

Ortner, P. B., Hulbert, E. M., Wiebe, P. H. (1979). Phytohydrography, Gulf Stream rings, and herbivore habitat contrasts. J. exp. mar Biol. Ecol. 39: 101-124

Paffenhöfer, G.-A. (1980). Zooplankton distribution as related to summer hydrographic conditions in Onslow Bay, North Carolina, Bull mar. Sci. 30: 819-832

Paffenhöfer, G.-A., Deibel, D., Atkinson, L. P., Dunston, W. M. (1980). The relation of concentrations of suspended particulate matter to hydrography in Onslow Bay, North Carolina. Deep Sea Res. 27: 435-448

Paffenhöfer, G.-A., Wester, B. T., Nicholas, W. D. (1984) Zooplankton abundance in relation to state and type of intrusions onto the southeastern United States shelf during summer. J. mar. Res. 42: 995-1017

Pietrafesa, L. J., Janowitz, G. S. (1980). On the dynamics of the Gulf Stream front between Cape Canaveral and Cape Hatteras. Second Int. Symp. Strat. Flows, Trondheim, Norway, p. 184-195

Pocklington, R. (1979). An oceanographic interpretation of seabird distributions in the Indian Ocean. Mar. Biol. 51: $9-21$

Snedecor, G. W., Cochran, W. G. (1980). Statistical methods. Iowa State Univ. Press, Ames, Iowa

Tasker, M. L., Jones, P. H., Dixon, T., Blake, B. F. (1984). Counting seabirds at sea from ships: a review of methods employed and a suggestion for a standardized approach. Auk 101: 567-577

Tranter, D. J., Tafe, D. J., Sandland, R. L. (1983). Some zooplankton characteristics of warm-core eddies shed by the East Australian Current, with particular reference to copepods. Aust. J. mar. Freshwat. Res. 34:587-607

Wiebe, P. H., Hulbert, E. M., Carpenter, E. J., Jahn, A. E., Knapp, G. P., Boyd, S. B., Ortner, P. B., Cox, J. L. (1976). Gulf Stream cold-core rings: large scale interaction sites for open-ocean plankton communities. Deep Sea Res. 23: $695-710$

Yoder, J. A., Atkinson, L. P., Lee, T, N., Kim, H. H., McClain, C. R. (1981). Role of Gulf Stream frontal eddies in forming phytoplankton patches on the outer southeastern shelf. Limnol. Oceanogr. 26: 1103-1110

Yoder, J. A., Atkinson, L. P., Bishop, S. S., Hofmann, E. E., Lee, T. N. (1983). Effect of upwelling on phytoplankton productivity on the outer southeastern U.S. continental shelf. Cont. Shelf Res. 1: 385-404 